\title{
NARATOR SEBAGAI PENYAMPAI KRITIK SOSIAL DALAM NOVEL MOHA LE FOU MOHA LE SAGE KARYA TAHAR BEN JELLOUN
}

\author{
Tania Intan \\ Fakultas Ilmu Budaya Universitas Padjadjaran \\ tania.intan@ unpad.ac.id
}

\begin{abstract}
In each literary work, the author through the narrator conveys his ideas or criticisms of an issue that is the inspiration of his writing. A novel in French, Moha le Fou Moha le Sage (MFMS) by Tahar ben Jelloun, illustrates the delivery of certain ideas and criticisms with the social background of the newly independent Maghreb state from French colonization. This research was made to describe the conditions that were criticized and the way the narrator expressed his criticism. The sociology of literature approach is used, to study the object of the novel MFMS research. Data was collected by reading and recording techniques, and analyzed using descriptive analytic techniques. The results show that the criticized conditions in this novel relate to a very sharp dichotomy in social configuration, between strong and weak, male and female, employer and slave, white and black, educated and not. The narrator, Moha, speaks as himself to convey the plight of the weak that are unable or prevented from speaking up. He gives advice, reprimands, reminds, threatens, and persua des him to be heard. But all his efforts were in vain because people were generally too busy looking for money and were reluctant to stop listening to other people's complaints.
\end{abstract}

Key words: Moha le Fou Moha le Sage, Tahar ben Jelloun, social critics

\section{A. LATAR BELAKANG}

Dalam pembelajaran bahasa dan sastra Prancis, terlihat bahwa kesusastraan Prancis tidak lagi didominasi oleh karyakarya pengarang Prancis, tapi juga diwarnai tulisan para pengarang frankofon. Mereka berasal dari wilayah bekas jajahan Prancis yang mendapatkan kemerdekaan pada akhir tahun 1950-an. Walaupun karya-karya mereka berlatar belakang sosial, ekonomi, budaya, geografi, dan tradisi berbeda, namun ada hal yang mempersatukan, yaitu penggunaan bahasa Prancis. Tema-tema yang sering dikembangkan pengarang frankofon di antaranya adalah perbudakan, kolonisasi, kritik budaya, pencarian identitas, dan juga rasisme.

Untuk menegaskan kekhususan mereka, para pengarang frankofon menunjukkan kualitas dan gaya penulisan yang khas dengan penggunaan bahasa
Prancis yang sempurna. Sejumlah pengarang frankofon pun mendapat hadiah sastra yang bergengsi seperti Prix Goncourt, yang salah satu di antaranya diraih Tahar ben Jelloun.

Tahar Ben Jelloun adalah penulis asal Maroko yang banyak menulis dalam bahasa Prancis (Blondeau, 2004). Ia lahir di Fès tanggal 1 Desember 1944. Setelah menyelesaikan studi bilingual ArabPrancis, ia belajar di sekolah menengah Prancis di Tanger. Pada umur 18 tahun, ben Jelloun melanjutkan pendidikannya di jurusan filsafat di Universitas Mohammed$\mathrm{V}$ di Rabat dan menulis untuk pertama kali kumpulan puisinya yang berjudul Hommes sous linceul de silence (1971).

Ben Jelloun mengajar filsafat di Maroko, dan kemudian pergi ke Prancis pada tahun 1971 karena semua pelajaran diarabisasi, padahal dia tidak merasa dilatih untuk itu. Dia pun menulis beberapa artikel 
untuk harian Le Monde dari tahun 1972. Ben Jelloun memperoleh gelar doktor psikiatri sosial pada tahun 1975 . Tulisannya banyak terinspirasi dari pengalamannya sebagai psikoterapis (La Réclusion solitaire, 1976). Pada tahun 1985 ia menerbitkan novel L'Enfant de sable yang membuatnya terkenal. Ia memenangkan Prix Goncourt pada 1987 untuk La Nuit sacrée. Saat ini, ben Jelloun menjadi pengajar di beberapa perguruan tinggi.

Salah satu karyanya yang menarik untuk dikaji dan menjadi objek untuk penelitian ini adalah novel Moha Le Fou Moha Le Sage 'Moha si Gila Moha si Bijak'. Sebagai narator, Moha banyak berbicara untuk mewakili tokoh-tokoh lain yang dibungkam atau tidak mampu bersuara, yang terdiri dari kaum lemah di dalam tatanan sosial masyarakat Magribi setelah kemerdekaan bangsa itu. Dengan berbagai cara, Moha meminta perhatian orang-orang di jalan untuk mendengarkan ceritanya. Untuk mempelajari hal tersebut, dalam tulisan ini telah diidentifikasi permasalahan-permasalahan penelitian, yaitu berkaitan dengan (1) kondisi-kondisi yang dikritik oleh narator dan (2) cara narator menyampaikan kritiknya.

\section{B. LANDASAN TEORI}

Sosiologi sastra dipandang Wolf (Faruk, 1994: 3) sebagai suatu disiplin yang tanpa bentuk, terdiri atas berbagai studi empiris pada teori yang lebih general, yang masing-masing memiliki satu kesamaan, yaitu sama-sama mengaitkan sastra dengan masyarakat. Ada tiga perspektif dalam kajian sosiologi sastra. Pertama perspektif teks sastra, artinya peneliti menganalisis sebagai sebuah refleksi kehidupan masyarakat dan sebaliknya, kedua perspektif biografis yaitu peneliti menganalisis pengarang, dan ketiga perspektif reseptif, yaitu peneliti menganalisis penerimaan masyarakat terhadap teks sastra (Endraswara, 2003: 80). Perspektif yang digunakan pada penelitian ini adalah perspektif teks sastra, yaitu dengan cara menganalisis teks sastra, mengklasifikasi, kemudian menjelaskan makna sosiologisnya. Dalam penelitian ini, aspek yang dianalisis adalah kritik sosial, yaitu anggapan bahwa karya sastra merupakan cerminan dari masyarakat. Artinya, sastra yang merupakan hasil karya pengarang yang hidup di masyarakat melukiskan masalah dan peristiwa yang memang terjadi. Masalah sosial yang terjadi dalam masyarakat dapat dikurangi atau bahkan diatasi dengan berbagai cara, termasuk dengan mengemukakan kritik. Hal ini sesuai dengan teori tindakan yang dikemukakan Talcott Parsons (Beilharz, 2003: 293), bahwa tindakan adalah perilaku yang disertai aspek "upaya" subyektif dengan tujuan membawa kondisi situasional atau "isi kenyataan", lebih dekat dengan keadaan "ideal" atau yang ditetapkan secara normatif. Melalui kritik sosial, diharapkan masalah-masalah sosial yang terjadi di dalam masyarakat dapat diatasi, sehingga keadaan yang ideal dan harmonis pun terwujud.

Setiap cerita dalam karya sastra tidak dapat dipisahkan dari para tokoh yang merupakan mahluk fiktif atau imajinatif yang masing-masing memiliki fungsi dan perannya dalam pergerakan cerita (Goldenstein, 1980: 44). Berdasarkan fungsinya, tokoh dapat merupakan tokoh utama, tokoh pembantu, atau tokoh tambahan. Tokoh biasanya ditampilkan dengan deskripsi fisik dan mental, yang keterangannya diperoleh secara langsung dari pengarang, melalui penjelasan tokoh lain, atau dari tokoh itu sendiri. Informasi tentang tokoh juga dapat berasal dari benda-benda yang dimilikinya, ucapannya, atau tingkah lakunya.

Berkaitan dengan sudut pandang, ada dua tipe narasi menurut Goldenstein (1980: 33), yaitu: vision illimitée (sudut pandang tidak terbatas) dan vision limitée (sudut pandang terbatas). Pada sudut pandang tidak terbatas, narator tidak hadir dalam cerita, namun ia mendominasi plot dan para 
tokoh. Pengetahuannya tentang segala hal tidak terbatas. Narator mampu menyajikan pada pembaca pikiran-pikiran rahasia atau bahkan yang tidak disadari oleh para tokoh. Selain itu, narator juga mampu memaparkan segala hal rinci tentang seorang tokoh yang tidak diketahui tokoh lain.

Pada sudut pandang tidak terbatas, narator memiliki keterbatasan untuk mengisahkan ceritanya karena ia hanya dapat menyampaikan apa yang ia lihat, dengar, atau ketahui. Ciri yang terlihat jelas adalah dengan peran narator-agen atau protagonis, yang biasanya menggunakan kata ganti akuan. Narator terlibat dalam cerita, dapat menjadi tokoh utama atau tokoh pembantu.

\section{ANALISIS}

\section{Ringkasan Cerita Moha Le Fou} Moha Le Sage

Di negeri Magribi, semua orang mengenal Moha yang selalu dikelilingi oleh anak-anak jalanan. Moha memiliki karakter polos dan cerdas. Ia mengembara untuk menyampaikan kata-kata dari mereka yang dibungkam, keinginan dari mereka yang dibatasi, lagu-lagu mati, dan teriakan mereka yang teraniaya.

Moha kadang terlihat meracau di tempat umum untuk bercerita tentang kisah-kisah tabu dan rahasia dalam sebuah keluarga kaya dan berkuasa. Karena dianggap mengganggu, Moha kemudian ditangkap beberapa orang jahat yang membunuh dan menguburnya tanpa nisan. Tapi dari bawah makam itu, Moha terus berbicara untuk menyuarakan suara orangorang yang teraniaya.

\section{Kelompok Tokoh Dominan dan Yang Didominasi}

Dalam novel MFMS, terdapat lebih dari dua puluh tokoh yang masing-masing memiliki perannya, baik sebagai tokoh utama, pendukung, atau tambahan. Para tokoh yang relevan dibahas melalui klasifikasi berdasarkan pada keberpihakan
Moha. Selain sebagai tokoh utama, Moha juga berfungsi sebagai juru bicara yang menyampaikan gugatan dari kelompok pertama, para tokoh yang teraniaya, terhadap kelompok kedua, kelompok yang berkuasa.

\subsection{Moha}

Berdasarkan judul novel MFMS, dapat diketahui bahwa tokoh Moha merupakan figur misterius dan enigmatik. Ia gila (fou) tapi juga bijak (sage). Umurnya telah sangat tua tapi ia berparas dan memiliki tubuh laki-laki berumur empat puluh tahunan.

Tubuh tuanya berumur lebih dari satu abad. Tanpa kerutan sedikitpun, raganya seperti seorang anak, pandangannya terarah lembut memandang rakyat jelata (Ben Jelloun, 1978: 157)

Kondisi fisik ini tentunya tidak normal terjadi pada laki-laki yang telah sangat tua, tapi juga menjadi logis mengingat Moha bukan seorang manusia biasa. Sejak kelahirannya, Moha telah ditinggalkan sang ayah di dekat mata air. Alamlah yang membesarkannya melalui ibunya, seorang budak perempuan berkulit hitam. Moha belajar dari alam, ia berbicara dengan pohon dan binatang. Dari mereka, Moha mendapatkan banyak pengetahuan dan kebijaksanaan.

Karena merasa tidak ada yang mengikatnya, Moha pun tidak pernah tinggal di tempat yang sama. Sebagai pribadi yang bebas, ia pergi ke mana pun ia mau, dan tidur di mana pun yang ia inginkan.

Aku tidak punya rumah. Bangunan membuatku sesak. Oh! Jangan berlebihan! Aku tidur di mana saja. Tapi bukan di bank. Aku tidur di pantai. Aku mengamati bulan dan terbang di atas daratan (Ben Jelloun, 1978: 23). 


\section{0 | JURNAL ILMU BUDAY}

Dengan pembawaan yang ringan dan kelembutan tatapannya, Moha hidup menggelandang dari satu tempat ke tempat lain. Banyak anak menyukainya, karena ia dianggap sebagai penjaga mereka di waktu malam. Sebaliknya Moha juga menyayangi mereka, terutama yang bernasib malang. Moha membenci orang tua anak-anak itu, yang membiarkan anaknya menderita, mengeksploitasi, hingga menjual mereka dengan alasan kemiskinan.

Moha pun mencoba mengingatkan orang-orang dewasa untuk mencintai anakanaknya, dan pada mereka yang mengabaikan kata-katanya, ia melontarkan ancaman. Selain berpihak pada anak-anak, Moha juga memiliki empati mendalam pada para perempuan yang tertindas dan dieksploitasi laki-laki. Ia selalu mengingatkan mereka untuk memperjuangkan keadilan yang merupakan takdir mereka.

Lengkapi diri kalian dengan pisau silet dan rusak wajah (laki-laki) dan harga diri mereka. Oh, aku mendengar teriakan kalian. Di tengah malam aku terbangun dan teringat pada kalian (Ben Jelloun, 1978: 46-47)

Tingkah lakunya yang ganjil membuat Moha dianggap sebagai orang gila, terlebih ia berbicara tidak jelas di sembarang tempat. Secara ironis, sekalipun biasanya ia menerima julukan tersebut, ada kalanya Moha menolak dan meminta orang-orang di jalan mendengarkannya.

Dengan kondisi kejiwaannya yang dianggap terganggu, Moha ternyata sangat nasionalis. Ia melawan imperialisme Prancis di negerinya. Ia sangat memuja Magribi dan mengungkapkan kecintaan pada tanah air dalam kata-katanya. Ia juga berkali-kali meneriakkan kemarahannya terhadap segala bentuk penjajahan, sehingga berkali-kali pula tentara Prancis menangkap dan memukulinya. Namun berkat kegilaannya, Moha selalu dibebaskan keesokan harinya.
Setelah masa kemerdekaan, ternyata situasi di negaranya tidak berubah menjadi lebih baik. Banyak kalangan berlombalomba mencari jabatan untuk memperkaya diri. Itulah sebabnya Moha membenci uang dan dampaknya pada manusia, sehingga ia tidak segan merobek uang yang dimilikinya di depan sebuah bank. Ia mengejek mereka yang terjebak dalam dunia materialis, individualis, dan selalu terburu-buru seolah menjadi budak uang.

Sialan, mengapa aku bisa melihat yang kalian tidak bisa lihat? Itu mungkin karena kalian telah tertutup, tenggelam dalam pakaian wol impor itu. Kulit kalian kedap dari semua pesan, dari setiap panggilan. Kulit kalian keriput tapi tidak terbuka (Ben Jelloun, 1978: 21).

Meskipun kebenciannya pada orangorang seperti itu sangat mendalam, Moha masih berbaik hati untuk memberi nasihat yang bijaksana, agar mereka tidak bekerja terlalu keras, karena itu akan mendatangkan masalah dalam hidup mereka.

Kamu misalnya, kalau terus bekerja seperti itu, kamu akan sakit punggung, dan istrimu akan pergi bersama sepupumu, si bandit itu. Dan kamu, kamu tidak bisa menghentikan waktu, majikanmu yang gemuk itu akan terus menaikimu seperti binatang (Ben Jelloun, 1978: 30)

Pada suatu hari, Moha ditangkap karena kata-katanya mulai dianggap meresahkan dan membahayakan. Setelah diperiksa oleh seorang psikiater muda, Moha dipukuli sampai mati oleh beberapa laki-laki tidak dikenal. Namun ternyata sekalipun telah mati, kata-kata Moha terus didengar oleh mereka yang percaya padanya, bahwa yang dinyatakannya adalah kebenaran.

Seolah dipanggil dari dalam tanah oleh Moha, anak itu dan teman-temannya 


\section{1 | JURNAL ILMU BUDAY}

berkumpul pada suatu malam di pemakaman orang miskin. Pohon pun bergeser. Ia membuat bayangan teduh bagi makam itu dan para pengunjung. Moha pun berbicara dengan tenang (Ben Jelloun, 1978: 161).

Dari sitasi-sitasi tersebut dapat diketahui karakter, latar belakang kehidupan dan peran Moha dalam cerita. Pada bagian berikutnya, akan dibahas tokoh-tokoh yang suaranya dibungkam oleh tokoh-tokoh lain, yang akan dikaitkan dengan keberadaan Moha sebagai pembawa pesan orang-orang malang yang tidak dapat bersuara. Dengan mengabaikan rasa benci dan marahnya pada mereka yang materialis, egois, selalu tergesa-gesa dan tidak peduli pada sesama, Moha menasihati mereka dan mengingatkan bahaya uang bagi kemanusiaan. Ucapan-ucapan Moha merupakan ramuan dari kegilaan yang cerdas dan kebijakan ironis, yang tidak dapat dipahami oleh semua orang.

\subsection{Tokoh-tokoh yang Terbungkam}

Para tokoh yang termasuk ke dalam kategori ini tentunya adalah mereka yang berada di pihak Moha, yang terdiri dari orang-orang tertindas. Mereka menitipkan pesan pada Moha untuk menyampaikan hal-hal yang tidak dapat mereka ungkapkan karena berbagai alasan. Ada enam tokoh yang berada di sisi ini, yaitu Ahmed, Aïcha, Dada/ Fatem Zohra, seorang anak yang terlahir dewasa, Moché, dan Dhaouya.

\section{a. Ahmed}

Rachid Ahmed adalah tokoh pertama yang teriakannya didengar oleh Moha. Pemuda yang tampan, pemberani dan idealis ini disiksa dan diinterogasi oleh sejumlah tentara di ruangan bawah tanah. Yang ia lakukan sebenarnya hanyalah berdemonstrasi pada pemerintah untuk mendapatkan air bagi para petani.

Selama mengalami penyiksaan, ia memikirkan kenangan-kenangan indah bersama keluarganya. Tapi resistensi semacam itu tidak lama bertahan, karena tubuhnya terus menerus disakiti, ia pun memohon untuk diampuni. "Orang-orang itu menyakiti tubuhnya, menyobeknya, menjahitnya. Mereka menusuk-nusuk dan menyalakan api di kepalanya (Ben Jelloun, 1978: 19)".

Moha sebagai pelindung orang-orang teraniaya dan anak-anak mendengar dalam mimpinya suara Ahmed, seorang anak negeri yang sedang dianiaya. Karena bingung dan tidak berdaya, Moha hanya dapat menjerit dan menyumpahi orangorang yang tidak peduli dan seperti tuli, tidak mau membantu pemuda itu.

Moha tahu benar bahwa orang-orang yang tergesa-gesa berlalu lalang di jalan itu egois dan berpura-pura tidak mendengar apapun karena mereka pengecut. Mereka tahu apa yang terjadi, tapi tidak mau melakukan apapun. Dan ketika suara Ahmed tidak lagi terdengar di telinganya, Moha tahu anak itu sudah mati. "Anakku mati! Di antara tangan besi mereka. Kebencian membunuhnya ... Apa yang akan mereka lakukan sekarang dengan mayat itu? (Ben Jelloun, 1978: 110)”.

Meskipun tidak memiliki hubungan langsung apapun dengan Ahmed, Moha dapat merasakan siksaan telah yang diterima oleh pemuda itu. Ia tidak dapat memahami bagaimana pemerintah dapat bertindak begitu kejam pada rakyatnya sendiri. Pemerintah negeri yang baru yang seharusnya melindungi warganya justru menunjukkan represi dan otoritas untuk memperlihatkan kuasanya.Kekuatan katakata Moha dalam situasi ini menjadi tumpul dan tidak berguna.

\section{b. Aïcha}

Sebelum menjadi pelayan di rumah Tuan Besar, gadis berumur dua belas tahun ini adalah seorang petani. Seperti semua saudarinya, ia dijual sang ayah pada orang kaya dengan alasan kemiskinan. Aïcha merasa tidak senang dengan perbuatan ayahnya itu, dan membayangkan seandainya Moha, kakeknya ada di 


\section{2 | JURNAL ILMU BUDAY}

dekatnya. Sekalipun banyak orang menganggap pria tua itu gila, tidak sedikitpun Aïcha malu karenanya.

Aku sangat menyayangi kakekku. Ia sering marah dan menunjuk-nunjuk langit kalau lama tidak turun hujan. Ia juga memaki para petani yang menurut saja pada keinginan para tuan tanah, seperti milik mereka saja, mereka yang bertindak sewenang-wenang atas nama tanah air dan Tuhan. Kakekku dihormati karena ia selalu menyatakan kebenaran (Ben Jelloun, 1978: 44).

Menurutnya, kata-kata sang kakek sangat kuat, lebih kuat daripada Tuan Besar, majikannya. Kekuatan kata-kata itu akan lebih terasa saat Moha marah. Pria ini tahu dan mendengar saat Aïcha merasa lelah dalam pekerjaannya, saat gadis itu merasa sedih karena diabaikan. Karena keberadaannya sering tidak dianggap, pada suatu hari Aïcha pergi ke hutan dan tidak kembali, namun tidak ada yang menyadari kepergiannya itu.

Gadis ini melambangkan orang-orang miskin dan lemah yang sejak masa mudanya sudah sangat menderita. Ia dijual ayahnya, harus bekerja keras di rumah Tuan Besar, tanpa perlindungan dari siapapun.

\section{c. Dada atau Fatem Zohra}

Selain tentang Aïcha, Moha juga mengisahkan cerita seorang budak perempuan berkulit hitam yang bernama Fatem-Zohra dan biasa dipanggil Dada. Karena Dada bisu, Mohalah yang menjadi juru bicara baginya. Ia dibeli oleh Tuan Besar sepulangnya dari tanah suci.

Dia bernama Dada. Itu bukan nama yang sesungguhnya. Ia dipanggil Dada sebagaimana semua perempuan kulit hitam yang dibawa dari Afrika oleh tuan besarnya. Dada membawa barangbarang milik majikannya dan tidak pernah membuka mulut. Bisu, ya dia juga bisu (Ben Jelloun, 1978: 53).

Sebagai seorang perempuan berkulit hitam, Dada menjalani hidup yang berat dan menyedihkan sejak kelahirannya. Ia dijual oleh keluarganya, dia tidak pernah mengalami masa muda. Semua kemalangannya diakibatkan situasi di negerinya, Sudan, karena kebrutalan matahari dan kelaparan. Ia ditemukan sedang mengemis oleh Tuan Besar, lalu dibawa ke rumahnya di Magribi. Karena ia cantik dan menurut, seksualitas Dada dieksploitasi secara brutal. Dengan penuh keterpaksaan, Dada harus melayani semua keinginan majikannya yang cabul itu.

Karena tidak mampu menahan lagi penderitaannya, muncul ide dalam pikiran Dada untuk membunuh Tuan Besar, tapi ia sedang hamil. Harapan untuk memiliki anak sedikit membuatnya bahagia, kehamilannya itu menempatkan dirinya sebagai istri kedua.

$\mathrm{Si}$ perempuan bisu, kata-kata pertamanya adalah teriakan panjang dan melengking, sebuah kelahiran. Ia memanggil putrinya Dhaouya. Sebuah nama yang hebat. Dhaouya artinya dia yang membawa cahaya, kejernihan, dan keabadian. Dada sangat bahagia. Tidak ada seorang pun yang dapat merenggut kebahagiaannya sebagai seorang ibu, meskipun dia hanya istri diam-diam, penghasil keturunan kelas dua (Ben Jelloun, 1978: 59).

Niat membunuh suaminmya pun dilakukan Dada yang meracuninya dengan pil ajaib. Tapi ternyata pil tersebut hanya membuat laki-laki itu sakit parah. Pada usahanya yang kedua, Dada berubah pikiran, ia membuat laki-laki itu semakin cinta padanya, lebih daripada perempuan kulit putih istri pertamanya. Tapi yang terjadi adalah Tuan Besar menjadi gila. Dada pun pergi meninggalkan rumah itu dengan putri kecilnya. 


\section{3 | JURNAL ILMU BUDAY}

\section{d. Anak yang terlahir dewasa}

Moha kemudian bercerita tentang kehidupan seorang anak laki-laki yang tidak menyerupai anak-anak lain. Tubuhnya tidak berbeda, namun pikirannya cenderung gelap dan aneh padahal ia baru berumur 12 tahun. Ia suka naik pohon dan mengkhayal.

Anak itu tidak keren. Ia pemikir berat. Ada emosi berupa kekosongan di wajahnya. Ketika sedih, ia akan memanjat sebuah pohon dan bermimpi. Ia bertanya-tanya kapan bisa masuk ke masa kanak-kanaknya. Ia terlahir dewasa, sebagaimana anak-anak terlahir cacat (Ben Jelloun: 76).

Sejak lahir, anak itu selalu sendiri, seperti Moha yang ditinggalkan di dekat sebuah mata air dalam kotak karton. Anak itu menganggap mata air sebagai ibunya dan seekor kuda sebagai ayahnya. Awal hidupnya sangat mirip dengan Moha. Tapi anak itu menyadari bahwa ia sebenarnya belum dewasa namun merasa bingung karena tidak memiliki sedikitpun kenangan tentang masa kecil. Ia terpaksa untuk menjadi dewasa, ia harus mendapatkan uang untuk membiayai hidupnya.

Untuk menenangkan hatinya, ia sering pergi ke mesjid, sampai suatu hari ia berhenti mengunjungi tempat itu. Seorang imam muda memintanya untuk menjadi mata-mata kelompok revolusioner. Tapi karena memiliki jiwa bebas, anak itu menolak dan mulai pergi ke kuburan untuk mencari ketenangan.

Aku juga akan menyingkir ke dalam makam. Untuk bermeditasi (...) aku berpikir tentang hidup. Bukan hidupku. Tidak ada yang perlu dipikirkan dari hidupku. Tapi hidup orang lain, mereka yang mengejar uang, mereka yang percaya bahwa kebahagiaan ada dalam toples, toples itu ada di kebun, dan kebun adalah mimpi yang diceritakan oleh nenekku. Aku juga berpikir tentang kematian. Kematianku (Ben Jelloun, 1978: 81-82).

Moha dapat mengerti apa yang dirasakan anak itu. Mereka merasakan mimpi, kecemasan, dan keinginan yang sama. mereka juga merasa bingung karena tidak mengalami masa kanak-kanak. Hidup terasa terlalu pahit akibat perang. Selepas perangpun, tidak ada yang berubah. Moha yang sangat menyayangi anak-anak merasa kuatir dengan masa depan mereka, dan pesimis dengan adanya kemajuan di negeri itu.

\section{e. Moché}

Laki-laki Yahudi tua ini adalah teman Moha, dan keduanya memiliki karakter serupa. Mereka senang berbicara dengan pohon, mencintai kebebasan dan kegilaan. Di masa lalu, meskipun kaum Yahudi dianggap memiliki reputasi buruk, Moché dikenal sebagai penyihir hebat yang sering membantu orang-orang termasuk syeik muslim mengusir roh jahat.

Aku bertanya-tanya, mengapa di tempat kita, orang Yahudi memiliki reputasi sebagai penyihir hebat? Aku adalah orang Yahudi yang buruk, aku tidak percaya dogma agama, dan aku tidak memuja setan, aku justru mengusirnya (Ben Jelloun, 1978: 118).

Berbeda dengan masa mudanya, sekarang Moché selalu sedih dan muram. Baru ketika Moha mengunjunginya, ia sedikit cerita mengingat masa-masa menyenangkan penuh kegilaan. Ia selalu mengeluh tentang anak-anaknya yang terlalu sibuk dan orang-orang pada umumnya yang tidak mengerti arti bersenang-senang. Mereka terus bekerja mencari uang seperti orang sakit mengejar obat.

Mereka takut pada kegilaan (...) karena di sana mereka hidup tanpa puisi, tanpa 


\section{4 | JURNAL ILMU BUDAY}

keleluasaan, tanpa kelembutan. Mereka berbisnis. Mereka terburu-buru di jalan. Suatu hari nanti, mereka akan kehilangan hidup di bawah sinar matahari (...) Orang-orang sekarang tidak lagi gila. Mereka sakit (Ben Jelloun, 1978: 119).

Pertemuannya dengan teman lama ini justru membuat Moha bertambah bingung dan pesimis, karena ia merasa kesepian. Ia lalu melanjutkan perjalanannya untuk mewujudkan misinya menasihati orangorang yang tak acuh, seperti anak-anak Moché agar lebih peduli pada penderitaan dan rasa kesepian orang lain, termasuk ayah mereka.

\section{f. Dhaouya}

Anak ini adalah putri Tuan Besar dari budaknya, Dada, yang kemudian menjadi istri keduanya. Meskipun sangat disayangi ayahnya dan menyandang nama keluarga itu, Dhaouya telah diincar oleh istri pertama ayahnya. "Dia tidak akan lama di sekolah. Aku akan membutuhkannya sebentar lagi untuk mengerjakan pekerjaan rumah tangga (Ben Jelloun, 1978: 63).

Setelah kematian sang ayah dan kepergian Dhaouya dan Dada dari rumah itu, Dhaouya tumbuh menjadi anak yang kuat dan rasionalis.

Dhaouya akan berkata, "Jangan, Bu! Sihir tidak menghasilkan apapun. Kau akan membalas tindakan barbar dengan tindakan barbar lainnya. Kemudian kau menyembunyikan diri. Tidak! Hadapi kekejaman majikan yang mencuri hidupmu itu, harus ada kekejaman yang lebih besar. Jangan membalasnya dengan perbudakan lagi. $\mathrm{Ya} \mathrm{Bu}$, aku mengerti, penderitaanmu sangat dalam ... (Ben Jelloun, 1978: 65).

Tokoh Dhaouya ini menunjukkan adanya perlawanan dari pihak yang didominasi. Karakternya yang tangguh membuatnya layak untuk menggantikan sosok Moha dalam menyuarakan kebisuan sang ibu, Dada.

\subsection{Para Tokoh yang Berkuasa}

Pada bagian ini, yang dibahas adalah para tokoh antagonis yang berada di pihak dominan, yang memiliki kuasa untuk membungkam mereka yang didominasi. Yang termasuk di dalam kelompok ini adalah: Tuan Besar, istri Tuan Besar, anak laki-laki sulung, direktur bank, dan psikiater muda.

\section{a. Tuan Besar}

Pria ini merupakan tokoh yang terpandang di dalam masyarakat yang memanggilnya Sidi. Tubuhnya kecil, sifatnya keras dan kasar. Sepulangnya dari berhaji, ia membawa Dada, seorang budak kulit hitam yang mengejutkan keluarganya dan membuat cemburu istri Tuan Besar. Pria itu sangat tergila-gila pada tubuh budaknya dan memanfaatkannya kapan pun ia menghendaki.

Sebagai laki-laki yang dikenal relijius dan dermawan oleh masyarakat sekitar, ternyata Tuan Besar sangat kejam pada kaum perempuan, terutama pada Dada yang disukainya. Namun ia merayakan kelahiran Dhaouya, putrinya dengan Dada, dalam pesta besar sesuai tradisi.

Karena guna-guna yang dikirim Dada padanya, Tuan Besar mengalami sakit jiwa yang parah. Ia tidak merawat diri, juga berkata-kata kasar dan tidak senonoh sehingga membuat malu keluarganya. Moha pun datang untuk mengobati dan menasihatinya.

Tiba-tiba ketika sadar pada suatu hari, laki-laki ini memutuskan untuk pergi kembali ke tanah suci, tapi kali ini ia meninggal karena terinjak-injak jamaah lainnya. Dalam kematiannya, ia datang dalam mimpi istri pertamanya dan berpesan untuk tidak mengganggu Dada dan putrinya. Ia juga menyempatkan diri dalam mimpi itu untuk berkeluh kesah tentang situasi tidak nyaman yang dialami di tempatnya sekarang. 


\section{5 | JURNAL ILMU BUDAY}

Kalian mengirimku mati di padang pasir ini di mana hidup manusia tidak berharga. Kalian berpesta-pesta sedangkan aku menjerit karena sebal ada di bukit yang bau ini, di mana orang miskin bercampur dengan orang kaya, orang cacat dengan orang gagah. Sungguh memalukan (Ben Jelloun, 1978: 84).

Moha memang sangat membenci lakilaki ini yang mengkhianati istrinya, dan memperlakukan budaknya dengan buruk. Terlebih lagi, Tuan Besar sepanjang hidupnya mengklaim diri sebagai orang yang alim dan relijius. Bagi Moha, hal itu hanya bentuk kemunafikan semata.

\section{b. Istri Tuan Besar}

Perempuan ini berkulit putih dan berasal dari keluarga kaya raya. Saat Dada datang ke rumahnya sebagai budak suaminya, perempuan ini merasa cemburu dan selalu menyiksa budak itu setiap ada kesempatan.

Karena kemarahannya, si istri berkulit putih memukuli Dada setiap kali Tuan Besar pergi. (...) Dada dipukuli saat tidur, dan hanya makan dua hari sekali (Ben Jelloun, 1978: 61).

Ketika suaminya menjadi gila karena perbuatan Dada, perempuan ini menunjukkan rasa cintanya dengan mengundang orang tuanya, dan imam mesjid besar untuk mengusir roh jahat. Tapi usaha itu sia-sia saja. Dan setelah kematian sang suami, hidupnya didedikasikan bagi kebahagiaan putranya saja. Sebagai perempuan, ia pasti merasa menderita karena suaminya, tapi ia tetap setia karena memiliki anak-anak yang harus dilindungi. Untuk itulah Moha menunjukkan rasa simpatinya, tapi pendidikan dan kasih sayang berlebihan yang diberikan perempuan itu pada anak laki-lakinya yang sulung, membuatnya menjadi individu yang materialis dan egois.

\section{c. Anak laki-laki sulung}

Seperti ibunya, anak ini tidak menyukai Dada dan saudara tirinya yang berkulit hitam. Ketika sang ayah mengalami kegilaan, anak laki-laki ini mengurus bisnis ayahnya dan menjadi majikan muda. Saat Moha datang sesudah kematian sang ayah, sebuah pesta diadakan di rumah itu untuk merayakan keberhasilan si anak sulung dalam pekerjaannya.

Dengan kesuksesannya itu, pemuda ini mengkritik Moha dan usahanya yang dianggap sia-sia. Menurutnya, untuk mendapatkan uang, tidak cukup dengan hanya bicara. Ia harus mengeksploitasi para pekerja, memberi mereka upah minimum, menjebloskan mereka dalam penjara jika para pekerja itu meminta haknya dan ia juga siap menyuap aparat pemerintahan untuk memudahkan langkah-langkahnya.

Anak laki-laki sulung Tuan Besar itu membanggakan pendidikannya yang berlatar Barat. Menurutnya, yang paling penting adalah uang, kata-kata Moha tidak ada harganya sama sekali.

\section{d. Direktur Bank}

Tokoh lain yang berada di pihak berseberangan dengan Moha adalah direktur bank. Ia selalu sibuk hingga penyakit insomnia menyerangnya. Hidupnya selalu kekurangan waktu, sehingga setiap saat ia mengeluh.

Moha pun mendatanginya dan mengingatkan agar direktur bank lebih peduli pada sekitarnya, agar penyakitnya menjadi lebih ringan. Moha masih peduli pada pria ini karena ia tidak korupsi, meskipun dapat menerima bila orang lain melakukannya. Menurut direktur bank, korupsilah yang menggerakkan ekonomi negara.

Negara kita, mengakui melakukan dan membiarkan orang melakukan korupsi. Secara moral itu memang salah. Tapi 
moral tidak menggerakkan perekonomian. Agama? Agama melarang korupsi, seperti juga melarang pencurian, kebohongan dan lain-lain. Jika kita benar-benar muslim, seharusnya kita menutup semua bank. Pada saat kita membuat uang dengan uang semua sudah salah. Jadi ya sudah, singkirkan saja moral dan agama itu (Ben Jelloun, 1978: 126-127).

Dengan prinsip hidup yang berbeda, direktur bank itu sulit menerima masukan dan nasihat dari Moha. Sedih karena merasa gagal dalam misinya, Moha pun pergi. Ia tidak mengerti mengapa orang yang memiliki kuasa seperti direktur bank tidak berpikir untuk menolong orang-orang yang membutuhkan.

\section{e. Psikiater Muda}

Setelah ditangkap dan dijebloskan ke penjara, Moha dipertemukan dengan seorang psikiater muda yang akan memeriksanya. Yang terjadi, setelah bertanya tentang identitas Moha, psikiater itu malah mengeluhkan hidupnya yang kekurangan uang.

Di sini aku berlelah-lelah, dan mendengarkan orang-orang sakit, bagusnya aku menjadi pegawai sosial saja! Tapi aku takut kehilangan semua yang sudah aku dapatkan. Aku purapura menjadi dokter saja. Aku terus memberikan obat-obatan. Yang menyebalkan, pemerintah tidak punya cukup uang untuk membeli obat penenang yang aku butuhkan. (...) Di sini aku merasa tidak berguna (Ben Jelloun, 1978: 152).

Psikiater ini lulusan dari sekolah di Eropa dan mengadopsi prinsip-prinsip Barat, sehingga ia tidak setuju dengan sosialisme dan sistem pengobatan gratis yang diterapkan pemerintah baru setelah kemerdekaan. Moha berusaha memahami jalan pikiran laki-laki itu, dan menurutnya alasan dari kegilaan yang dialami banyak orang di negara itu adalah karena tercerabut dari akar budayanya sendiri, banyak orang tidak mengenali identitasnya.

Psikiater muda itu mengabaikan katakata Moha dan malah bercerita tentang sepupunya, seorang apoteker yang memanfaatkan kondisi sakit para pasien. Sepupunya itu tidak peduli pada penderitaan orang lain, yang dipikirkannya adalah keuntungan besar yang didapat dari situasi seperti itu. Baginya kemanusiaan tidak ada arti sama sekali.

Aku akan bersikap seperti sepupuku (...) Selama ia sekolah, ayahnya, pedagang kaya, mencarikan tempat untuk apotik di daerah ramai yang padat penduduk. Kenapa? Bukan untuk hiasan di sana, tapi di daerah kumuh seperti itu banyak orang sakit, dan apoteker akan menjadi sangat kaya (Ben Jelloun, 1978: 154).

Bingung mendengar penjelasan seperti itu, Moha pun menuduh psikiater muda orang jahat, tapi sebaliknya pria itu balik menuduh Moha. Menurutnya si laki-laki tua itu punya kekuatan jahat, yang menghipnotisnya menjadi banyak bicara.

Tuan Besar, istri pertama, dan putra mereka, direktur bank dan juga psikiater muda merupakan tokoh-tokoh yang secara sosial ekonomi berada pada tingkat lebih tinggi dibandingkan dengan tokoh-tokoh lain. Mereka memiliki uang dan posisi dalam masyarakat, namun Moha tidak menyukai mereka seperti mereka tidak menyukai dirinya. Mereka tidak ingin mendengar kritikan dan ancaman Moha yang menganggap mereka tidak peduli dan tidak mau mendengar suara-suara penderitaan sesamanya.

\section{Sudut Pandang Narator terhadap Pembungkaman Suara Rakyat Magribi}

Dari awal cerita telah diketahui bahwa narator adalah Moha. Pengetahuannya 


\section{7 | JURNAL ILMU BUDA Y A}

tentang segala hal tidak terbatas. Ia mampu menyampaikan pada pembaca pikiranpikiran rahasia para tokoh, bahwan hal-hal yang tidak mereka sadari.

Sesuai dengan judul novel MFMS, Moha adalah orang fou 'gila' sekaligus sage 'bijak', maka sifat penceritaannya pun tentu tidak akan menyerupai penceritaan orang kebanyakan. Figur pencerita gila memang lazim ditemukan dalam dongengdongeng dengan kultur Magribi. Dan sebagai orang gila, Moha tidak takut kehilangan, dan ia memiliki kebebasan untuk berbicara tanpa batasan atau etika diplomasi. Namun sebagai orang bijak, ada kebenaran dan kenyataan yang ia nyatakan, sekalipun tidak nyaman didengar. "Aku gila. Jadi aku bisa berkata apa saja! (Ben Jelloun, 1978: 135)."

Moha bercerita karena ia ingin menyembuhkan penyakit-penyakit yang ada di masyarakat, yang membuat mereka menderita. Tindakan kuratif ini dipraktikkan dengan cara memberi nasihat. Sebagai orang bijak, ia adalah orang yang peduli, paham, dan ingin membenahi situasi yang salah yang sedang terjadi di negerinya.

Karena ia sendiri yang berbicara, Moha menggunakan kata ganti orang pertama akuan, dengan sifat penceritaan omniscient. Yang ia sampaikan adalah suara-suara yang dititipkan mereka yang tidak dapat berbicara. "Kata-katanyalah yang kita dengar. Hanya Moha yang dapat menangkap dan menyampaikannya pada yang lain (Ben Jelloun, 1978: 9)."

Namun tidak semua orang mau mendengarnya, terlebih kata-kata itu diucapkan seorang laki-laki gila. Itulah sebabnya Moha merasa frustasi dan mengungkapkan kemarahannya sehingga ia bertanya alasan mereka mengabaikannya.

Kalian mau ke mana? Mengapa kalian tidak mau mendengar suara seorang anak yang tersesat di bawah tanah karena siksaan dan ketidakadilan? (Ben Jelloun, 1978: 19)
Karena sangat marah, Moha tidak lagi memilih kata-katanya dengan baik. Ia tidak paham mengapa orang-orang yang ia teriyaki itu begitu tuli dan buta. "Dasar setan, mengapa kalian tidak dapat melihat apa yang aku lihat? (Ben Jelloun, 1978: 21). Moha pun tidak tahu lagi harus dengan cara apa ia mengingatkan orang-orang itu, sehingga ia pun mengutuk mereka.

Tapi kalian tidak mendengarkanku! Kalian berpura-pura tidak ada! Kalian menutup telinga dengan lembar-lembar uang, kalian kehilangan pendengaran, nanti kalian akan kehilangan penglihatan juga. Lalu kalian akan mengalami impotensi! Istri-istri kalian akan pergi, tapi tidak semua sayangnya, beberapa akan pergi ke hutan. Anakanak kalian sudah pergi tapi kalian tidak sadar ... (Ben Jelloun, 1978: 37)

Ternyata kutukannya pun tidak didengar, sehingga Moha memutuskan berganti strategi agar orang-orang itu mau berhenti berjalan dan mendengarkannya. Moha menawarkan untuk bercerita apa saja yang ingin didengar orang-orang yang tak acuh itu.

Mengapa kalian tidak mau mendengarku? (...) Aku punya cerita lain untuk kalian ... Jangan takut, aku hanya ingin memberikan kata-kata untuk kalian, cerita, lagu ... Aku tidak punya senjata atau kebencian untuk pagi kalian yang pucat, untuk malam kalian yang hampa ... (Ben Jelloun, 1978: 138).

Yang ingin disampaikan Moha pada mereka sebenarnya adalah simpati dan pembelaannya untuk kaum tertindas. Tapi ia memiliki perhatian khusus terutama pada perempuan Magribi. Sepanjang perjalanan hidupnya Moha telah mengobservasi, menjadi saksi, berpikir, dan sekarang adalah waktu baginya untuk 


\section{8 | JURNAL ILMU BUDAY}

menyampaikan. Menurut Moha, perempuan seharusnya menempati posisi primordial dalam masyarakat, namun kenyataannya, untuk mendapatkan pengakuan itu, perempuan harus berjuang terlebih dulu. Tapi tetap saja mereka dianggap sebagai warga kelas dua.

Hari-hari berlalu di antara jari-jari dan kalian menyembunyikan tato. Kalian menggarap tanah siang hari dan melayani laki-laki kalian di waktu malam. Kalian mengangkut tumpukan jerami di punggung sementara laki-laki itu ada di depan di atas keledainya. Ah nasib! (...) Kalian selalu bersiap untuk bekerja di ladang atau untuk berperang. Ya kalianlah yang berperang melawan orang-orang Prancis itu (Ben Jelloun, 1978: 47).

Kata-katanya itu ditujukan pada kaum perempuan Magribi untuk memperlihatkan keberpihakannya, menunjukkan kasih sayangnya, dan secara implisit mengingatkan mereka untuk bereaksi. Moha menyalahkan kaum laki-laki di negerinya yang pada umumnya bersembunyi di belakang dogma agama untuk membenarkan tindakan abusif mereka pada perempuan. Moha menuduh mereka hanya mengaku-ngaku sebagai orang Islam tapi tidak berlaku seperti yang seharusnya.

Selain pada perempuan, Moha juga menunjukkan dekadensi moral dan tindakan antihumanisme yang parah terjadi dalam masyarakat Magribi setelah merdeka. Ia tidak paham bagaimana pihak yang kuat memanfaatkan secara maksimal kelemahan dan ketidaktahuan pihak yang lain.

Kau memiliki sejumlah petani yang bekerja di tanah-tanahmu, dan kau menganggap mereka sebagai pengemis yang kau bayar secukupnya, kau atur supaya mereka selalu miskin. Apa kau lupa mereka itu manusia? (Ben Jelloun, 1978: 72)

Moha pun mengungkapkan bahwa dalam masyarakat Magribi saat itu ada dua hal yang dianggap penting yaitu agama Islam dan uang (Ben Jelloun, 1978: 52). Jadi, orang yang merasa relijius sekalipun akan berupaya untuk memperkaya diri karena uang membuatnya dapat melakukan banyak hal.

Mereka memiliki semua. Uang dan kekuasaan. Uang dan brutalitas. Mereka tidak malu. Dan mereka ada di manamana. Mereka memiliki pabrik, bank dan perempuan di sana-sini. Pada hari Jumat, mereka pergi sembahyang (Ben Jelloun, 1978: 30).

Pada dasarnya memang Moha tidak suka uang dan pengaruh buruknya pada manusia. Ia pun mengingatkan orang-orang muslim untuk mengambil uang mereka di bank dan tidak terlalu menghargainya sebagai dewa. Ia pun menunjukkan sikap pelecehan pada uang dengan cara menyobek-nyobeknya di depan bank. Alihalih didengarkan dan diikuti, Moha ditangkap pihak aparat dan keesokan harinya ia mati karena disiksa.

Setelah menganalisis sudut pandang novel ini, dapat diketahui bahwa narator tidak hanya memaparkan fenomena sosial yang terjadi dalam masyarakat Magribi setelah kemerdekaan bangsa itu. Dengan memposisikan diri sebagai tokoh dalam cerita dengan menggunakan kata ganti orang pertama tunggal, ia maha tahu. Narator dapat masuk dalam pikiran para tokoh.

Dari kajian juga dapat ditemukan gagasan tentang humanisme, feminisme dan rasisme. Hal ini menunjukkan bahwa sesudah masa kemerdekaan bangsa Magribi pun, kolonialisme tidak benar-benar lenyap namun berganti wajah dan pelaku. Di masa kini, penjajah dan yang dijajah berasal dari bangsa yang sama. Melalui observasi 


\section{9 | JURNAL ILMU BUDA Y A}

Moha, diketahui adanya dikotomi dalam konfigurasi sosial antara pihak yang kuat dan yang lemah, yaitu: pemerintah $><$ rakyat, orang kaya $><$ orang miskin, orang dewasa $><$ anak-anak, majikan $><$ budak, $\quad$ putih $><$ hitam, lakilaki $><$ perempuan, dan Barat $><$ Timur.

Untuk melawan situasi itulah, Moha menjadi juru bicara 'porte parole' yang menggunakan kekuatan kata-katanya. Namun kematiannya di akhir cerita menunjukkan bahwa perjuangannya dibatasi oleh kekuatan lain yang lebih besar.

\section{SIMPULAN}

Novel MFMS berpusat pada tokoh utama Moha, seorang lelaki penuh misteri, yang berpindah tempat dengan sesuka hati dan senantiasa meneriakkan jeritan kaum teraniaya (wanita, budak belian, anak-anak, orang lanjut usia, dan kaum minoritas) kepada orang-orang tak acuh yang bergegas melintas di hadapannya. Dengan penuh kebencian, Moha menyobek uang kertas di depan sebuah bank untuk menunjukkan bahwa manusia saat ini terlalu materialis dan egois, sehingga menjadi tuli untuk mendengarkan keluh kesah penderitaan sesamanya, bangsa Magribi.

Namun demikian, kekuatan kritik dalam kata-kata Moha harus berhadapan dengan tembok tirani pemerintahan baru setelah bangsa Magribi merdeka. Politik represif pun berusaha membungkam sang pencerita tua untuk selamanya. Dari dalam kuburnya, Moha terus berbicara untuk menyampaikan seluruh kebenaran, walau terasa pahit bagi yang mendengarnya.

Sebagai tokoh protagonis, Moha dianggap gila karena sikap dan tingkah lakunya tidak sesuai dengan norma yang berlaku saat itu. Namun demikian, ia juga dianggap sebagai orang bijak, karena sebenarnya Moha menyampaikan kenyataan hidup yang pahit yang dialami oleh sebagian besar rakyat bangsa bekas jajahan Prancis itu. Ia juga berani meneriakkan hal-hal yang tidak dapat disampaikan orang lain, seperti penjajahan, pembunuhan aktifis muda, perlawanan wanita, dan kritik terhadap sistem patriarki berkedok agama.

Latar sosial Magribi yang tidak banyak berubah pada masa sebelum maupun setelah kemerdekaan menunjukkan bahwa penindasan manusia atas manusia lain dapat dilakukan oleh orang yang sebangsa. Kemajuan dan modernitas yang diraih malah memacu banyak orang menjadi lebih materialis dan egois, sehingga tidak lagi dapat berempati terhadap penderitaan orang lain. Kesenjangan sosial yang terjadi pun memperkeruh suasana. Keberadaan agama Islam yang sangat melekat dalam kehidupan sehari-hari malah sering disalahgunakan untuk kepentingan para penguasa.

Sudut pandang tidak terbatas yang mendominasi novel ini sesuai dengan karakter kemahatahuan (omniscient) dari tokoh utama yang mampu menyelami pikiran dan perasaan tokoh-tokoh lain. Jenis sudut pandang ini mendukung tugas Moha sebagai seorang penyampai pesan, atau juru bicara dari kaum teraniaya. Ia berusaha dengan berbagai cara untuk menyapa, menegur, mengingatkan, memarahi, bahkan mengancam orangorang yang tak acuh dengan kehadirannya. Moha berada di pihak kaum lemah, yang berarti: rakyat, bangsa Magribi, orang miskin, perempuan, anak-anak, bangsa kulit hitam, budak, dan budaya Timur. Dengan kebebasan yang dimilikinya sebagai orang gila (fou) namun bijak (sage), Moha tidak berhenti untuk mengingatkan tentang kemanusiaan yang hampir hilang dari muka bumi ini.

\section{DAFTAR RUJUKAN}

Beilharz, Peter. 2003. Teori-teori Sosial. Yogyakarta: Pustaka Pelajar. 
Ben Jelloun, T. (1978). Moha le Fou Moha le Sage. Paris : Editions du Seuil.

Blondeau, N. (2004). Littérature Progressive $d u$ français niveau débutant. Paris : CLE International.

Brahimi, D. (2001). Langue et Littératures francophones. Paris : Ellipses.

Deniau, X. (1987). Florilège de la langue française et de la francophonie. Paris : Editions Richelieu-Senghor.

Endraswara, S. (2003). Metode Penelitian Sastra. Yogyakarta: Pustaka Widyatama.

Faruk. 1994. Pengantar Sosiologi Sastra. Yogyakarta: Pustaka Pelajar.

Goldenstein, J.P. (1980). Pour Lire le roman. Brussel-Paris : De BoeckDuculot.

Guidère, M. (2003). Méthodologie de la recherche. Paris : Ellipse.

Joubert, J-L. (2006). Petit guide des littératures francophones. Paris: Nathan.

Le Marchand, V. (1999). La Francophonie. Ligugé : Les Essentiels Milan. 